\title{
Import of proteins into the peroxisomal matrix
}

\author{
Sohel Hasan ${ }^{1}$, Harald W. Platta ${ }^{2 *}$ and Ralf Erdmann ${ }^{1 *}$ \\ 1 Systembiochemie, Medizinische Fakultät, Ruhr-Universität Bochum, Bochum, Germany \\ ${ }^{2}$ Biochemie Intrazellulärer Transportprozesse, Medizinische Fakultät, Ruhr-Universität Bochum, Bochum, Germany
}

Edited by:

Richard Rachubinski, University of

Alberta, Canada

Reviewed by:

Giovanni Solinas, University of

Fribourg, Switzerland

Maike Krenz, University of

Missouri-Columbia, USA

*Correspondence:

Harald W. Platta, Biochemie

Intrazellulärer Transportprozesse,

Medizinische Fakultät,

Ruhr-Universität Bochum,

Universitätsstr. 150, D-44780

Bochum, Germany

e-mail: harald.platta@rub.de;

Ralf Erdmann, Systembiochemie,

Medizinische Fakultät,

Ruhr-Universität Bochum,

Universitätsstr. 150, D-44780

Bochum, Germany

e-mail: ralf.erdmann@rub.de
Peroxisomes constitute a dynamic compartment in all nucleated cells. They fulfill diverse metabolic tasks in response to environmental changes and cellular demands. This adaptation is implemented by modulation of the enzyme content of the organelles, which is accomplished by dynamically operating peroxisomal protein transport machineries. Soluble import receptors recognize their newly synthesized cargo proteins in the cytosol and ferry them to the peroxisomal membrane. Subsequently, the cargo is translocated into the matrix, where the receptor is ubiquitinated and exported back to the cytosol for further rounds of matrix protein import. This review discusses the recent progress in our understanding of the peroxisomal matrix protein import and its regulation by ubiquitination events as well as the current view on the translocation mechanism of folded proteins into peroxisomes. This article is part of a Special Issue entitled: Origin and spatiotemporal dynamics of the peroxisomal endomembrane system.

\section{Keywords: peroxisome, protein import, ubiquitination, biogenesis, translocation, targeting}

\section{INTRODUCTION}

Peroxisomes are organelles that can be found in all nucleated cells. The number and morphology of peroxisomes varies significantly among different cell types, tissues or species. Peroxisomes are typically spherical organelles with a diameter from 0.1 to $1 \mu \mathrm{m}$ that are surrounded by a single phospholipid bilayer membrane.

The peroxisomal luminal proteins are tightly packed in electron-dense, sometimes even crystalline matrix. The enzyme content varies depending on the cellular demands with the ability to adjust to the metabolic requirements of the cell. Accordingly, peroxisomes are considered to be multi-purpose organelles that contribute to the adaptation of cells to different environmental conditions. The peroxisomal matrix can harbor at least 50 different enzymes that are involved in diverse biochemical processes, such as beta-oxidation of fatty acids and the detoxification of hydrogen peroxide, which are considered as a main functions of peroxisomes (Schlüter et al., 2010). The beta-oxidation of fatty acids exclusively takes place in peroxisomes in yeast and plants, while in the case of mammalian cells, only the very long chain fatty acids (VLCF) are oxidized in peroxisomes, whereas shorter chain fatty acids are oxidized in mitochondria. Additionally, it has been established that peroxisomes are required for the synthesis of plasmalogens and bile acids in mammals (Wanders and Waterham, 2006) and that they contribute to certain biochemical steps of photorespiration of plants ( $\mathrm{Hu}$ et al., 2012) as well as the final steps of penicillin biosynthesis in some filamentous fungi (Meijer et al., 2010). More recently explored functions of peroxisomes include an partial involvement in Vitamin K biosynthesis in plants (Babujee et al., 2010;
Widhalm et al., 2012), calcium homeostasis in mammals (Lasorsa et al., 2008) as well as pheromone production in nematodes and insects (Joo et al., 2010; Spiegel et al., 2011). Moreover, peroxisomes contribute to the iron uptake and therefore virulence of pathogenic Aspergillus species, by containing enzymes required for the biosynthesis of siderophores (Gründlinger et al., 2013).

Typical peroxisomes together with specialized peroxisomes like glyoxysomes, glycosomes and Woronin bodies constitute the organelle family of "microbodies," whose members are all evolutionary related, sometimes even interconvertible compartments. The glycosomes of the protist order Kinetoplastida harbor glycolysis enzymes, whereas the glyoxysomes of the germinating plant seeds house enzymes of the glyoxylate cycle, and the Woronin bodies of filamentous fungi are tightly packed with a crystalline protein and function to seal septal pores in response to wounding (Pieuchot and Jedd, 2012).

The pivotal role of the correct topogenesis of peroxisomal proteins is also pointed out by the fact that dysfunction of human peroxisomes is associated with a spectrum of severe peroxisomal disorders, like e.g., Zellweger syndrome or X-linked adrenoleukodystrophy (Baes and Van Veldhoven, 2012; Nagotu et al., 2012; Poll-the and Gärtner, 2012; Waterham and Ebberink, 2012). These different disorders have in common that they are characterized by an abnormal peroxisome assembly and impaired peroxisomal function, in many cases resulting in multisystemic disorders that lead to death in early infancy. Furthermore, recent data demonstrate a link of peroxisome function and antiviral innate immunity as that they can promote a rapid response to 
viral infection via peroxisomal antiviral signaling proteins (Dixit et al., 2010). In addition, it has been demonstrated that functional peroxisomes counteract the progressive brain damage and cognitive decline found in Alzheimer's disease (Kou et al., 2011; Lizard et al., 2012). Finally, the reactive oxygene metabolism connects peroxisomes to the molecular process of aging (Giordano and Terlecky, 2012; Manivannan et al., 2012).

All of the mentioned physiologic tasks strictly depend on a proper compartmentalization of the corresponding enzymes, which itself relies on a proper peroxisomal biogenesis.

The biogenesis of peroxisomes conceptually consists of the (1) formation and proliferation of the peroxisomal membrane, (2) peroxisome movement and inheritance as well as (3) the topogenesis of peroxisomal membrane and (4) matrix proteins (Platta and Erdmann, 2007; Fagarasanu et al., 2010; Islinger et al., 2012; Liu et al., 2012; Theodoulou et al., 2013). These tasks are essentially carried out by peroxisomal biogenesis factors, the peroxins. From the 34 peroxins described so far, at least 19 are known to be directly involved in different stages of peroxisomal matrix protein import (Table 1). In this review, we will focus on the recent developments concerning the topogenesis of peroxisomal matrix proteins.

\section{MATRIX PROTEIN IMPORT}

Because peroxisomes do not contain genetic material, all of their protein content is encoded in the nucleus, synthesized on free polyribosomes in the cytosol and targeted to the organelle in a post-translational manner [reviewed in Leon et al. (2006a)]. Recent data suggest that already the mRNA of most of the analyzed peroxisomal proteins is targeted to the proximity area of the peroxisome prior to the translation step (Zipor et al., 2009, 2011). The capacity to import proteins in a fully folded or even oligomeric and co-factor bound state is an extraordinary feature of peroxisomes and differentiates peroxisomes from other classical organelles like mitochondria or chloroplasts [reviewed in Leon et al. (2006a)]. While this concept had been established quite early, the question whether folded cargo proteins are preferably imported in an oligomeric or monomeric state has been picked up by two recent studies. While one study finds that mammalian Pex5p strictly imports tetrameric catalase (Otera and Fujiki, 2011), another study suggests that the catalase oligomer may be disassembled during the import process (Freitas et al., 2011).

In general, peroxisomes share the capability to translocate folded proteins with the Twin-Arg-Translocation (Tat) pathway of bacteria and thylakoid membranes (Albiniak et al., 2012; Palmer and Berks, 2012). However, while the entire machinery required for the translocation of the substrate protein is membrane-bound in the case of the Tat-system, some of the constituents of the peroxisomal translocation apparatus are soluble (Schnell and Hebert, 2003). The peroxisomal import receptors cycle between the cytosol and the peroxisomal membrane (Dammai and Subramani, 2001; Nair et al., 2004). According to the dynamics of the import receptors, the protein import process into peroxisomes can be divided into five stages such as (1) cargo recognition in the cytosol, (2) docking of the receptor/cargo-complex at the peroxisomal membrane, (3) cargo translocation over the membrane, (4) release of the cargo into the peroxisomal matrix, and (5) receptor recycling (Figure 1A).

\section{CARGO RECOGNITION IN THE CYTOSOL}

Newly synthesized peroxisomal matrix proteins are transported to their destination by means of a targeting sequence. The majority of the matrix proteins harbors a peroxisomal targeting signal type 1 (PTS1) at the carboxy-terminus, which is defined by the amino acids SKL and variants of the motif fitting the consensus (S/A/C)-(K/R/H)-(L/A). Because also additional adjacent residues have an impact on the cargo-recognition, the definition of the PTS1 can be extended to a dodecamer (Brocard and Hartig, 2006; Chowdhary et al., 2012). The conserved receptor for the PTS1-signal is Pex5p, which recognizes the PTS1-sequence via a tetratricopeptide repeats (TPRs) containing domain within its carboxy-terminal half. Crystal structures of the cargo-loaded and unloaded PTS1-receptor revealed that cargo binding induces major conformational changes within the receptor, which might generate a docking-competent state of the receptor (Stanley et al., 2006; Shiozawa et al., 2009; Fodor et al., 2012).

The peroxisomal targeting signal type 2 (PTS2) sequence is the second known peroxisomal targeting determinant. It is usually located within the first 20 amino acids of the cargo protein and has been defined as a nona-peptide by the amino acid signal (RK)-(LVIQ)-XX-(LVIHQ)-(LSGAK)-X-(HQ)-(LAF) (Petriv et al., 2004; Lazarow, 2006). In plants, approximately one third of peroxisomal matrix proteins harbor a PTS2-signal (Lingner et al., 2011; Chowdhary et al., 2012), whereas in Saccharomyces cerevisiae only three proteins are known to use this targeting sequence (Grunau et al., 2009; Jung et al., 2010). The PTS2pathway is completely absent in Caenorhabditis elegans (Motley et al., 2000), Drosophila melanogaster (Faust et al., 2012) and the protist Phaeodactylum tricornutum (Gonzalez et al., 2011), which therefore import all matrix proteins via the PTS1-pathway.

The PTS2-cargo is recognized by Pex7p, which contains several tryptophan-aspartic acid (WD) repeats that mediate the binding. However, unlike the PTS1-receptor, Pex7p is necessary, but not sufficient to carry out all steps of the import process because it requires auxiliary proteins. These PTS2-co-receptors are the redundant Pex18p and Pex21p in S. cerevisiae, the orthologous Pex20p in most other yeasts and fungi as well as Pex5L, the longer of two splice isoforms of Pex $5 \mathrm{p}$, in mammals and plants (Schliebs and Kunau, 2006). Interestingly, Podospora anserina Pex20p has been reported to carry out a Pex7p-dependent function in matrix protein import as well as a Pex7p-independent function in meiocyte formation (Peraza-Reyes et al., 2011).

The targeting of a subset of peroxisomal matrix proteins does not essentially rely on one of the two classical targeting signals (Figure 1B). Some of these proteins can be co-imported via an association with canonical PTS-cargo proteins. This "piggy-back import" has been demonstrated for the enoyl-CoA isomerases Ecilp and Dcilp from S. cerevisiae (Yang et al., 2001) and the five acyl-CoA oxidase isoforms from Yarrowia lipolytica (Titorenko et al., 2002) and more recently also for mammalian $\mathrm{Cu} / \mathrm{Zn}$ superoxide dismutase (Islinger et al., 2009). Other proteins, like 
Table 1 | Peroxins involved in peroxisomal matrix protein import.

\begin{tabular}{|c|c|c|c|}
\hline Peroxin & Enzyme/activity & $\begin{array}{l}\text { Mw } \\
\text { (KDa) }\end{array}$ & Function \\
\hline Pex1p (PAS1) & AAA-type ATPase & 117.3 & $\begin{array}{l}\text { Binds Pex6p and is involved in the dislocation of the } \\
\text { PTS-receptors }\end{array}$ \\
\hline Pex2p (CRT1, PAS5) & Ubiquitin-protein ligase (E3), RING-domain & 30.8 & $\begin{array}{l}\text { Forms together with Pex10p and Pex } 12 p \text { the RING-complex } \\
\text { and is involved in the ubiquitination of the PTS-receptors }\end{array}$ \\
\hline Pex5p (PAS10) & PTS1 receptor, TPR-domain & 69.3 & $\begin{array}{l}\text { Receptor for the PTS1-signal; required for the PTS1-dependent } \\
\text { matrix protein import }\end{array}$ \\
\hline Pex6p (PAS8) & AAA-type ATPase & 115.6 & $\begin{array}{l}\text { Binds Pex1p and is involved in the dislocation of the } \\
\text { PTS-receptors }\end{array}$ \\
\hline Pex8p (PAS6) & Coordinator of protein import machinery & 68.2 & $\begin{array}{l}\text { Peripheral intraperoxisomal membrane protein; bridges } \\
\text { docking-and RING-complex; possibly involved in cargo } \\
\text { disassembly }\end{array}$ \\
\hline Pex10p (PAS4) & Ubiquitin-protein ligase (E3), RING-domain & 39.1 & $\begin{array}{l}\text { Forms together with Pex } 2 p \text { and Pex } 12 p \text { the RING-complex and } \\
\text { is involved in the ubiquitination of the PTS-receptors }\end{array}$ \\
\hline Pex12p (PAS11) & Ubiquitin-protein ligase (E3), RING-domain & 46.0 & $\begin{array}{l}\text { Forms together with Pex } 2 p \text { and Pex10p the RING-complex and } \\
\text { is involved in the ubiquitination of the PTS-receptors }\end{array}$ \\
\hline Pex17p (PAS9) & Docking complex & 23.2 & $\begin{array}{l}\text { Membrane-associated protein that forms the docking complex } \\
\text { with Pex } 14 p \text { and Pex17p }\end{array}$ \\
\hline Pex18p & PTS2-co-receptor & 32.0 & $\begin{array}{l}\text { Interacts with PTS2-receptor Pex7p; partially redundant with } \\
\text { Pex21p (in S. cerevisiae) }\end{array}$ \\
\hline Pex20p & PTS2-co-receptor & 37.8 & $\begin{array}{l}\text { Involved in PTS2-dependent protein import, mostly as } \\
\text { co-receptor of Pex7p (in most fungi, like e.g., P. pastoris) }\end{array}$ \\
\hline Pex21p & PTS2 protein import & 33.0 & $\begin{array}{l}\text { Interacts with PTS2-receptor Pex7p; partially redundant with } \\
\text { Pex21p (in S. cerevisiae) }\end{array}$ \\
\hline Pex22p (YAF5) & Peroxisomal protein import & 19.9 & $\begin{array}{l}\text { Membrane protein required the recruitment of Pex } 4 p \text { to the } \\
\text { peroxisomal membrane }\end{array}$ \\
\hline Pex26p & Membrane anchor of the AAA-peroxins & 33.9 & $\begin{array}{l}\text { Tail-anchored PMP that is involved in the recruitment of } \\
\text { mammalian Pex6p to peroxisomal membrane }\end{array}$ \\
\hline Pex33p (Pex14/17p) & Docking complex & 52.5 & $\begin{array}{l}\text { Part of the docking complex in filamentous fungi, e.g., } \\
\text { N. crassa }\end{array}$ \\
\hline
\end{tabular}

The names in brackets refer to the previous original designations in yeast. Except where indicated, the molecular mass refers to the S. cerevisiae protein. 


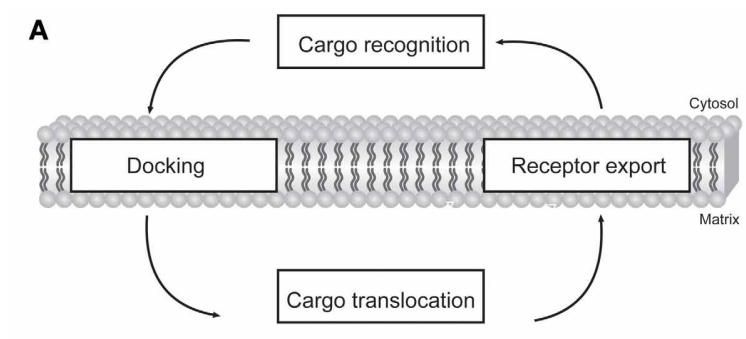

B

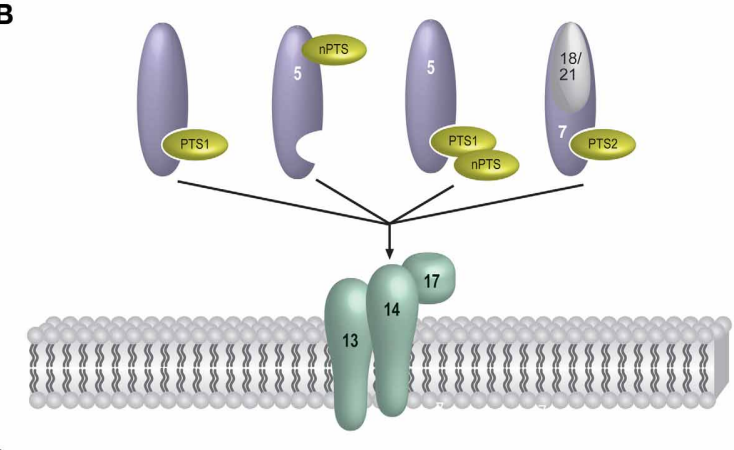

C
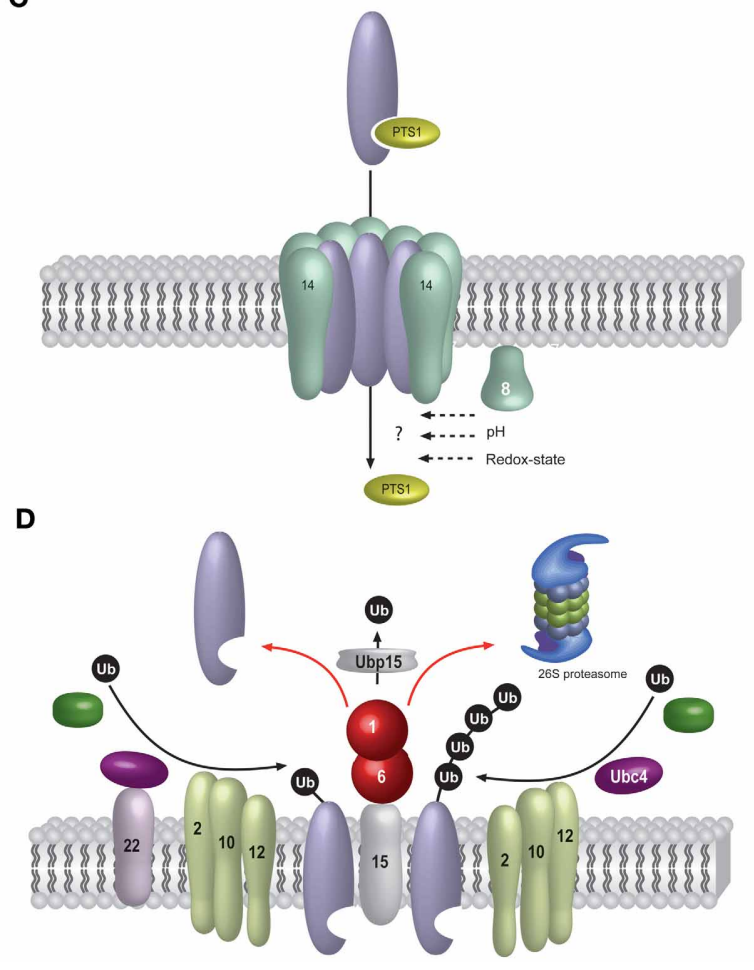

FIGURE 1 | Matrix protein import into peroxisomes. Most principles of peroxisomal protein import are evolutionary conserved. The schematic representation shown here refers to the situation in Saccharomyces cerevisiae. Peroxisomal matrix protein import takes place posttranslationally and requires an elaborate protein import machinery, consisting of peroxisome biogenesis factors, so called peroxins. (A) Another feature of peroxisomal import is the requirement for cycling receptors. The import process can conceptually be divided into cargo-recognition by the receptors in the cytosol, docking of the receptor/cargo-complex at the peroxisomal membrane, cargo translocation and finally export of the receptor back to the cytosol. (B) Cargo-recognition and docking: Proteins harboring a

(Continued)

\section{FIGURE 1 | Continued}

peroxisomal targeting signal of type 1 (PTS1) or type II (PTS2) are recognized in the cytosol by specific import receptors, Pex5p and Pex7p, respectively. Alternatively, some cargo proteins do not harbor a PTS or do not essential depend on it. Some of these non-PTS proteins (nPTS) bind to the N-terminus of Pex5p or to canonical PTS1-proteins. The cargo-loaded receptors are directed to a docking complex at the peroxisomal membrane. For this, the PTS2-receptor Pex7p requires auxiliary proteins, in baker's yeast these are the redundant Pex18p or Pex21p. The receptor-cargo-complexes bind to the docking-complex (Pex13p, Pex14p and Pex17p) at the peroxisomal membrane. The following steps are better known for the PTS1- than the PTS2-pathway. (C) Cargo-translocation: It is assumed that the association of Pex14p and cargo-loaded Pex5p leads to the formation of a transient pore, which functions as a protein-conducting channel. The cargo is translocated into the peroxisomal lumen in an unknown manner. In intraperoxisomal Pex8p, a pH-shift or the redox-state might be involved in receptor-cargo dissociation. (D) At the end of the import cascade, the receptor is recycled from the peroxisomal membrane back to the cytosol for another round of import. For this, Pex $5 p$ is monoubiquitinated by the Pex22p-anchored ubiquitin-conjugating enzyme Pex4p and the ubiquitin-protein ligase Pex12p, which forms the RING-finger complex together with the other ubiquitin-protein ligases Pex $2 p$ and Pex10p. Pex $5 p$-polyubiquitination is performed by the ubiquitin-conjugating enzyme Ubc4p in conjunction with the ubiquitin-protein ligases Pex $2 p$ and Pex10p. For Pex $5 p$, it has been demonstrated that the ubiquitin-signal leads to an ATP-dependent dislocation of Pex $5 p$ from the peroxisomal membrane. This process is performed by the AAA-type ATPases Pex $1 p$ and Pex6p, which are anchored to the peroxisomal membrane via Pex15p. During or shortly after receptor export to the cytosol, the ubiquitin is removed by the ubiquitin-hydrolase Ubp15p.

acyl-CoA oxidase from S. cerevisiae or alcohol oxidase from H. polymorpha (Klein et al., 2002; Gunkel et al., 2004), interact directly with Pex5p in a PTS1-independent fashion via the binding to the $\mathrm{N}$-terminal region of Pex5p in a process, which is called "non-PTS import" (Van Der Klei and Veenhuis, 2006).

A new chapter of peroxisomal targeting signals has recently been opened by the finding that glycolytic enzymes of the analyzed fungi and mammalian species contain a cryptic PTS (Freitag et al., 2012). With exception of the well-established glycolytic enzymes found in glycosomes of Kinetoplastids (Gualdrón-López et al., 2012) and the report on the peroxisome-dependent glucose metabolism of the fungus Cryptococcus neoformans (Idnurm et al., 2007), these enzyme were thought to be strictly cytosolic in all species. However, they contain a cryptic peroxisomal targeting signal, which can be generated or eliminated in a speciesspecific manner by ribosomal read-through or alternative splicing (Freitag et al., 2012). This differential targeting to two locations may indicate a dynamic regulation of glycolysis by sequestering the key enzymes away from the cytosol.

\section{ASSOCIATION OF THE CARGO-LOADED RECEPTOR WITH THE MEMBRANE VIA THE DOCKING COMPLEX}

Several lines of evidence indicate that only the cargo-bound receptors are efficiently directed to the peroxisome (Gouveia et al., 2003; Grunau et al., 2009). The cargo-bound receptors associate with the peroxisomal membrane via a docking complex (Figure 1B), which consists in all known species of the core components Pex13p and Pex14p (Kiel et al., 2006). The absence of 
either Pex13p or Pex14p significantly affects the import pathway of cargos targeted to the peroxisome (Azevedo and Schliebs, 2006; Williams and Distel, 2006). Pex13p is an integral membrane protein, which binds to Pex14p via its SH3-domain and also via an intraperoxisomal binding site (Pires et al., 2003; Schell-Steven et al., 2005). The N-terminal part of Pex13p also binds to the PTS2-receptor, while the SH3-domain of the yeast protein contains a binding site for the PTS1 receptor Pex5p (Williams and Distel, 2006). Pex14p contains a proline-rich segment for binding of the SH3-domain of Pex13p. Pex14p has been described as an carbonate-resistant integral membrane protein but in some species, it behaves like a peripheral protein (Azevedo and Schliebs, 2006). As Pex13p also Pex14p binds both PTS-receptors at different sites (Niederhoff et al., 2005). Nuclear magnetic resonance (NMR) and determination of the crystal structures (Neufeld et al., 2009; Su et al., 2009) revealed that the Pex5p/Pex14p interface comprises two hydrophobic cavities of Pex14p, which bind characteristic WXXXF/Y motifs of PTS1 receptor Pex5p. In general, Pex14p is considered to be the initial binding partner for the cargo-bound PTS1-receptor. However, because the available data addressing this question are limited and because of the observation that Pex13p can also associate with cargo-bound PTS-receptors (Grunau et al., 2009; Natsuyama et al., 2013), the individual contribution of Pex13p and Pex14p to the initial docking event remains to be further investigated.

In many species, the docking complex contains further peroxins in addition to Pex13p and Pex14p. Yeast Pex17p is a peripheral membrane protein of unknown function, which associates with peroxisomes via Pex14p but does not interact with Pex5p. A deficiency in Pex17p affects import of PTS1 as well as PTS2 proteins by an unknown mechanism (Azevedo and Schliebs, 2006). A homolog of Pex17p in higher eukaryotes has not yet been identified (Kiel et al., 2006). However, in filamentous fungi, a chimeric protein that consists of a Pex14p-like amino-terminal domain and a Pex17p-like carboxyl-terminal domain has been described (Managadze et al., 2010; Opaliński et al., 2010; Peraza-Reyes et al., 2011). This chimeric protein is called Pex14/17p in P. anserina and Penicilium crysogenum, while it is named Pex33p in Neurospora crassa.

Trypanosoma brucei contains two very different isoforms of Pex13p. While PEX13.1 resembles the conserved Pex13p, the PEX13.2 lacks the SH3 domain and contains a PTS1-signal at its carboxyl-terminus (Brennand et al., 2012; Verplaetse et al., 2012). It will be of interest to elucidate the special contribution of PEX13.2 to the protein import process, especially as it is part of the docking complex and essential for glycosome biogenesis.

A recent study of a Zellweger spectrum patient cell line describes the dimerization of human Pex13p (Krause et al., 2013). This dimerization occurs independently of the interaction to Pex14p and is required for PTS1-protein import (Krause et al., 2013). Also Pex14p can undergo dimerization, even though the functional impact is not understood yet (Su et al., 2010).

The association with the docking complex marks the entry of Pex5p to the protein-protein interaction network at the peroxisome (Hazra et al., 2002; Agne et al., 2003; Oeljeklaus et al., 2012). However, the collected data strongly indicate that components of the docking complex are far more than static receptor anchors and that they display a certain dynamic contribution to the peroxisomal protein import cascade.

\section{TRANSLOCATION OVER THE TRANSIENT IMPORT PORE AND CARGO-RELEASE INTO THE MATRIX}

The actual mode of matrix protein import is still elusive and how the cargo proteins traverse the peroxisomal membrane without affecting the permeability barrier remains hypothetical.

\section{Transient import pore}

Over the years, several models have been put forward of how folded and oligomeric proteins may traverse the peroxisomal membrane. The translocon has not yet been visualized and these models range from a channel consisting of multi-membrane spanning proteins and a transiently opened import pore to a pinocytosis-related model that completely lacks a translocon [as discussed in Girzalsky et al. (2009)].

The results collected in recent years strongly favor the idea of a transiently opened import pore (Figure 1C). It has been suggested that the major constituents of this dynamic pore may be membrane proteins Pex14p and Pex13p (Grou et al., 2009a) or Pex14p and the PTS1-receptor Pex5p (Erdmann and Schliebs, 2005). Indeed, one of the surprising features of Pex5p is that it can bind to lipids and change its topology at the peroxisomal membrane where it is partially carbonate resistant, adjusts to a partial protease-protected state and thereby behaves like an integral membrane protein (Gouveia et al., 2000, 2002; Platta et al., 2005; Kerssen et al., 2006). Furthermore, Pex5p together with Pex14p constitute the minimal unit for the translocation of the intraperoxisomal Pex8p across the membrane in $P$. pastoris (Ma et al., 2009). The functional interplay is further pointed out by the finding that at least in $\mathrm{CHO}$ cell lines, Pex5p can stabilize Pex14p (Natsuyama et al., 2013). Leishmania donovani Pex14p forms a homooligomeric complex, which undergoes major conformational changes upon Pex5p-binding (Cyr et al., 2008). Importantly, the Pex5p-Pex14p sub-complex of $S$. cerevisiae harbors pore forming activity in electrophysiological studies (Meinecke et al., 2010). This complex, which almost exclusively consists of Pex $5 p$ and Pex14p can be reconstituted into membranes and displays channel activity when incubated with a cargo-loaded soluble Pex5p (Meinecke et al., 2010). The size of this pore formed by the transiently gated ion conducting channel is variable up to $9 \mathrm{~nm}$ and therefore appears to accomplish the standards for the passage of folded proteins into the peroxisomal matrix. However, the exact composition of the pore as well as the driving force and the mechanism of cargo translocation remain elusive.

\section{Cargo release}

Data on how the cargo is released into the peroxisomal lumen are still scarce (Figure 1C). The first study to tackle this question directly suggests that the intraperoxisomal peripheral membrane protein Pex8p of $H$. polymorpha might be in involved in this process, because it can dissociate receptor-cargo complexes in vitro (Wang et al., 2003). In addition, the same study suggested that 
a change in $\mathrm{pH}$ might induce a disassembly of Pex5p-oligomers into the monomeric form and thereby also induces the dissociation of the cargo from this complex (Wang et al., 2003). A recent study in $P$. pastoris suggests that Pex8p is involved in a redox-state dependent disassembly of Pex5p oligomers and cargo (Ma et al., 2013). However, it is not easy to generalize these results because the intraperoxisomal $\mathrm{pH}$ may vary significantly depending on the experimental condition (Visser et al., 2007) and because Pex $8 p$ is a less conserved yeast protein that seems to be absent in most other species (Kiel et al., 2006). S. cerevisiae Pex8p has been described to function as a structural link of the docking complex to the export machinery (Agne et al., 2003; Platta et al., 2013), while this task is accomplished by Pex3p in P. pastoris (Hazra et al., 2002). One hypothetical explanation could be that the proposed role of Pex8p in cargo release may be transferred to the conserved parts of the docking complex in other species. In this respect, it is interesting to note that a recent publication demonstrates that the amino-terminus of mammalian Pex14p plays a role in the release of Pex5p-bound PTS1-cargo from the translocation machinery into the peroxisomal matrix (Freitas et al., 2011).

The signal sequence of a subset of the imported proteins is proteolytically removed after the import in peroxisomes of mammals and plants (Kurochkin et al., 2007; Schuhmann et al., 2008; Okumoto et al., 2011a). In the case of mammalian beta-oxidation enzymes, the intraperoxisomal protease Tysnd 1 is responsible both for the removal of the leader peptide from PTS2 proteins as well as for the processing of PTS1 proteins and controls thereby the proper activity of these enzymes in beta-oxidation (Okumoto et al., 2011a). Indeed, recent work demonstrates that a deficiency in Tysnd1 results in a mild Zellweger syndrome spectrum-resembling phenotype in mice (Mizuno et al., 2013).

\section{UBIQUITINATION AND DISLOCATION OF THE RECEPTOR BY THE EXPORTOMER}

Subsequent to cargo release, the receptor is exported to the cytosol by a molecular machinery called the peroxisomal exportomer (Platta et al., 2013). This machinery comprises sub-complexes consisting of mechano-enzymes that provide the pulling-force to extract the receptor from the membrane as well as sub-complexes that are required for the generation of the export-signal, which is the ubiquitination of the receptor (Figure 1D).

\section{Recycling pathway of the PTS1-receptor}

Most work has been dedicated to the ubiquitination of the PTS1-receptor Pex5p. Under wild-type conditions, the major modification of Pex5p is the attachment of a single ubiquitin moiety on a conserved cysteine residue (Kragt et al., 2005; Carvalho et al., 2007; Williams et al., 2007; Okumoto et al., 2011b). This monoubiquitination represents a prerequisite for the export of Pex5p back to the cytosol, which represents a molecular requirement that seems to be conserved from yeast to man (Carvalho et al., 2007; Platta et al., 2007, 2008; Okumoto et al., 2011b). The ubiquitin-conjugating enzyme (E2) Pex4p together with its membrane anchor Pex22p are required for this modification in S. cerevisiae (Platta et al., 2007; Williams et al., 2007, 2012). Mammalian cells lack clear Pex4p- and Pex22p-orthologs and here the functional-related isoforms $\mathrm{UbcH} 5 \mathrm{a}, \mathrm{UbcH} 5 \mathrm{~b}$ and $\mathrm{UbcH} 5 \mathrm{c}$ catalyze the cysteine-dependent monoubiquitination (Grou et al., 2008). Proper monoubiquitination of Pex5p depends on an intact RING-peroxin complex (Kragt et al., 2005; Williams et al., 2008; Platta et al., 2009). Work in S. cerevisiae has demonstrated that Pex2p and Pex12p (Platta et al., 2009) as well as Pex10p (Williams et al., 2008; Platta et al., 2009) display ubiquitin-protein ligase (E3) activity. Recently, it could be confirmed that also each of the A. thaliana RING-peroxins has E3 activity (Kaur et al., 2013). The deletion of one of the RING-peroxin genes causes the instability of the entire complex (Hazra et al., 2002; Agne et al., 2003) and therefore inhibition of monoubiquitination of Pex5p (Williams et al., 2008; Platta et al., 2009). However, in vitro ubiquitination studies with recombinant proteins as well as additional work with RING-peroxin truncations lacking the catalytic RINGdomain suggest that Pex12p is the E3 ligase directly responsible for monoubiquitination of Pex5p (Platta et al., 2009). At least in vitro, the activity of Pex12p can be synergistically enhanced in presence of the RING-domain of Pex10p (El Magraoui et al., 2012).

Following its monoubiquitination, the PTS1-receptor is exported back to cytosol in an AAA (ATPases associated with diverse cellular activities)-complex dependent manner. The peroxisomal AAA-type ATPases Pex1p and Pex6p play a nonredundant role in this process and are supposed to act as dislocases that extract the Pex5p from the membrane (Miyata and Fujiki, 2005; Platta et al., 2005). They are anchored to the peroxisomal membrane by the tail-anchored protein Pex15p in yeast as well as the orthologous Pex26p in mammals and APEM9 in plants (Birschmann et al., 2003; Matsumoto et al., 2003; Goto et al., 2011; Nashiro et al., 2011). The binding and hydrolysis of ATP by Pexlp and Pex6p is supposed to induce conformational changes that generate the force for the pull the receptor out of the membrane (Fujiki et al., 2012; Grimm et al., 2012). Although monoubiquitination of the PTS1-receptor plays a crucial role in its release, the exact molecular mechanism of substrate recognition and extraction from the membrane is still unclear. Interestingly, recent work from mammalian cells identified AWP1, which binds both Pex6p as well as ubiquitin (Miyata et al., 2012). This finding strongly suggest that AWP1 might function as specific linker, which enables the AAA-peroxins to transfer their pulling force to the monoubiquitinated receptor, thereby driving its export.

\section{Degradation pathway of the PTS1-receptor}

The cysteine-dependent monoubiquitination of Pex5p primes the PTS1-receptor for its recycling under normal conditions. However, in cases where the recycling pathway is hampered, Pex5 $\mathrm{p}$ is polyubiquitinated on lysine residues and finally degraded in the 26S proteasome (Platta et al., 2004, 2007; Kiel et al., 2005; Williams et al., 2007) (Figure 1D). The polyubiquitination of $S$. cerevisiae Pex5p mainly depends on the ubiquitinconjugating enzyme (E2) Ubc4p and the partially redundant Ubc5p and Ubclp (Platta et al., 2004; Kiel et al., 2005; Kragt et al., 2005). The RING-peroxins Pex10p (Williams et al., 
2008) as well as Pex2p (Platta et al., 2009) have been suggested to function as corresponding ubiquitin-protein ligases (E3). It is interesting to note that a recent in vitro study demonstrates that Pex10p(RING) can enhance the ubiquitination activity of the Ubc4p-Pex2p(RING) unit (El Magraoui et al., 2012), indicating that possibly these two RING-peroxins act together in the catalysis of the Ubc4p-dependent ubiquitination. The proteasomal degradation of the polyubiquitinated S. cerevisiae Pex5p is supposed to represent a quality control system for aberrant PTS1-receptor molecules (Platta et al., 2013).

\section{Deubiquitination}

Pex5p found in the cytosol is not further ubiquitinated in vivo, indicating that the ubiquitin moiety is removed upon or shortly after membrane release of the receptor (Figure 1D). In general, ubiquitin hydrolases perform the cleavage of ubiquitin from substrates (Amerik and Hochstrasser, 2004). The corresponding deubiquitinating enzyme in S. cerevisiae for the removal of the ubiquitin moiety from the modified PTS1receptor is Ubp15p (Debelyy et al., 2011), while the nonorthologous USP9X has been found to deubiquitinate the monoubiquitinated Pex5p in mammals (Grou et al., 2012). However, both studies suggest that also other deubiquitinating enzymes may act in a redundant manner on Pex5p. Furthermore, at least a minor fraction of the monoubiquitinated Pex5p can be deubiquitinated in a non-enzymatic manner by cleavage of the thioester bond between Pex5p and ubiquitin by a nucleophilic attack of glutathione (Grou et al., 2009b).

\section{Functional role of ubiquitination in the PTS2-import pathway}

The PTS2-co-receptor Pex18p of S. cerevisiae was the first peroxin that has been found to be ubiquitinated (Purdue and Lazarow, 2001). Recent studies analyzed the modified forms of PTS2co-receptors in more detail. This resulted in the discovery that Pex18p as well as the orthologous $P$. pastoris Pex20p are ubiquitinated in a similar manner to the PTS1-receptor Pex5p. Both Pex18p and Pex20p are polyubiquitinated on lysine residues and monoubiquitinated on a cysteine. The monoubiquitination is essential for matrix protein import, while the polyubiquitination regulates the stability of the PTS2-co-receptors (Leon et al., 2006b; Hensel et al., 2011; Liu and Subramani, 2013). Pex4p, the E2 ubiquitin-conjugation enzyme and the RING peroxins (Pex2p, Pex10p, Pex12p) proved to be required for mono- and polyubiquitination of $P$. pastoris Pex20p (Liu and Subramani, 2013). It is interesting to note that Pex18p displays a constitutive turn-over even in wild-type cells, while the PTS2-receptor Pex7p is stable (Hensel et al., 2011). So far, no evidence for ubiquitination or degradation of Pex7p has been found in yeast. However, a recent report demonstrates that endogenous Arabidopsis Pex7p is degraded by the proteasome when the dominant-negative GFP-Pex7p is expressed and that this mechanism depends on the interaction of Pex7p with the Rab GTPase RabE1c (Cui et al., 2013). However, it remains to be elucidated whether the observed disposal of Pex7p is also present under normal conditions and if this pathway is conserved among species.

\section{INTERCONNECTION OF RECEPTOR EXPORT AND CARGO IMPORT}

The peroxisomal export machinery components and the mechanism by which they facilitate the cycling of peroxisomal receptors are evolutionary and functionally related to endoplasmic reticulum associated degradation (ERAD) (Schlüter et al., 2006; Gabaldón, 2010; Schliebs et al., 2010). ERAD signifies a mechanism by which accumulated misfolded and polyubiquitinated proteins are extracted from the ER membrane or lumen for their subsequent degradation by the proteasome (Hampton and Sommer, 2012). Both the peroxisomal protein import machinery as well as the ERAD machineries utilize ubiquitination to mark proteins for their ATP-dependent release from the membrane by AAA-type ATPases.

The collected evidence over the last years defined the peroxisomal exportomer as the energy-consuming entity for peroxisomal protein import. In general, this might indicate that the step of cargo translocation into the matrix itself is an ATP-dependent step. However, a study with a rat liver in vitro system suggests that cargo release may occur independently of ATP and therefore presumably before the ubiquitination step (Alencastre et al., 2009). A CHO cell in vitro system instead supports the model that cargo translocation relies on the hydrolysis of ATP (Miyata et al., 2009). Along this line, it has been suggested that the ERAD-like ATP-driven export of the ubiquitinated receptor might be mechanistically linked to cargo translocation, which is highlighted by the so called export-driven-import model (Schliebs et al., 2010). In support of this model, the presence of a functional receptor-export complex is a pre-requisite for the ATP-dependent import of matrix proteins into peroxisomes (Schliebs et al., 2010). Current work on the ubiquitination of the PTS2-co-receptor Pex18p in S. cerevisiae provided direct evidence for the exportdriven-import model. The cysteine-dependent monoubiquitination of Pex18p, which is required for the export of the co-receptor from the peroxisomal membrane into the cytosol, was observed to be a prerequisite for translocation of cargo-loaded Pex7p across the peroxisomal membrane (Hensel et al., 2011). In this context, it is also interesting to note that the binding capacity for functional PTS-receptors at the peroxisomal membrane seems to be restricted. The attenuation of receptor export by functional impairment of the exportomer results in an accumulation of $S$. cerevisiae receptors at the membrane (Platta et al., 2004; Kiel et al., 2005) and therefore prevents the docking of incoming receptor-cargo complexes arriving from the cytosol. This assumption is in line with recent data from work in $A$. thaliana (Ratzel et al., 2011). The physiological defects of mutated and only insufficiently active Pex6p were partially restored when combined with a weakly expressed allele of the docking protein Pex13p (Ratzel et al., 2011). This strongly argues for a model in which PTS-receptor import and export rates have to be balanced to allow for a functional matrix protein import cascade.

In summary, the ATP-consuming peroxisomal receptor export machinery is thought to function as import motor for matrix proteins, either indirectly via balanced receptor import/export rates or directly via a linkage of cargo translocation with receptor ubiquitination and export. 


\section{CONCLUDING REMARKS}

The import of peroxisomal matrix proteins differs significantly from other organelles like mitochondria or chloroplasts as peroxisomes can accommodate folded and oligomeric proteins that are targeted to the membrane via cycling receptors.

Much progress has been made in the understanding of the molecular requirements for recognition of the PTS1-signal of peroxisomal matrix proteins by the import receptor Pex5p, for which even several atomic structures are now available. In contrast our knowledge of the structure of Pex7p and mechanism of cargo recognition is still limited. It also still needs to be addressed whether cargo recognition by the peroxisomal import receptors and peroxisomal targeting of the cargo-loaded receptor occurs more or less haphazardly in the cytosol or is also well regulated as indicated by the above mentioned studies on mRNA targeting.

It is now well accepted that the PTS1 receptor Pex5p cycles between a soluble cytosolic state and a membrane-bound state and recent evidence indicated that the receptor at the membrane forms an integral part of the temporally formed import pore. Clearly, it will be of importance to elucidate the assembly of this pore as well as the modulation of its dynamics and gating by regulatory proteins or posttranslational modifications. Apart from this, it will be a significant advance to clarify the existence of an independent PTS2-selective import pore. The functional role of the translocon-associated proteins, e.g., the Pex17p-like and Pex13p-like peroxins or Pex8p is not really understood and needs to be experimentally addressed.

The collected data on the concerted action of sub-complexes of the peroxisomal protein import machinery has merged into the unified model of the receptor export machinery, the exportomer.

In light of its important contribution to the energy requirement of peroxisomal protein import and the proposed exportdriven import model, the molecular dynamics of the exportomer during cargo translocation and export of the ubiquitinated receptor need to be investigated. Along this line, one of the most intriguing questions concerns the fact that the PTS1-receptor Pex5p as well as the PTS2-coreceptors Pex18p and Pex20p are ubiquitinated on a cysteine via a thioester bond and not by a more common isopeptide bond to a lysine. The functional relevance of this uncommon kind of ubiquitination remains to be disclosed.

Certainly, many questions regarding the molecular mechanism of matrix protein import into peroxisomes remain to be answered. This is also true for a possible cross-regulation of matrix protein import with other cellular processes, e.g., cellular redox-balance, nutrient and energy status as well as peroxisome maturation, division and degradation.

\section{ACKNOWLEDGMENTS}

We apologize to all the scientists whose work could not be cited due to space limitations. This work was supported by grants of the Deutsche Forschungsgemeinschaft (FOR 1905 'PerTrans') to Ralf Erdmann and Harald W. Platta.

\section{REFERENCES}

Agne, B., Meindl, N. M., Niederhoff, K., Einwächter, H., Rehling, P., Sickmann, A., et al. (2003). Pex8p. An intraperoxisomal organizer of the peroxisomal import machinery. Mol. Cell 11, 635-646. doi: 10.1016/S1097-2765(03)00062-5

Albiniak, A. M., Baglieri, J., and Robinson, C. (2012). Targeting of lumenal proteins across the thylakoid membrane. J. Exp. Bot. 63, 1689-1698. doi: 10.1093/jxb/err444

Alencastre, I. S., Rodrigues, T. A., Grou, C. P., Fransen, M., SáMiranda, C., and Azevedo, J. E. (2009). Mapping the cargo protein membrane translocation step into the PEX5 cycling pathway. J. Biol. Chem. 284, 27243-27251. doi: 10.1074/jbc.M109.032565

Amerik, A. Y., and Hochstrasser, M. (2004). Mechanism and function of deubiquitinating enzymes. Biochim. Biophys. Acta 1695, 189-207. doi: 10.1016/j.bbamcr.2004.10.003

Azevedo, J. E., and Schliebs, W. (2006). Pex14p, more than just a docking protein. Biochim. Biophys. Acta 1763, 1574-1584. doi: 10.1016/j.bbamcr.2006.09.002

Babujee, L., Wurtz, V., Ma, C., Lueder, F., Soni, P., Van Dorsselaer, A., et al. (2010). The proteome map of spinach leaf peroxisomes indicates partial compartmentalization of phylloquinone (vitamin K1) biosynthesis in plant peroxisomes. J. Exp. Bot. 61, 1441-1453. doi: 10.1093/jxb/erq014

Baes, M., and Van Veldhoven, P. P. (2012). Mouse models for peroxisome biogenesis defects and $\beta$-oxidation enzyme deficiencies. Biochim. Biophys. Acta 1822, 1489-1500. doi: 10.1016/j.bbadis.2012.03.003

Birschmann, I., Stroobants, A. K., Van Den Berg, M., Schäfer, A., Rosenkranz, K., Kunau, W. H., et al. (2003). Pex15p of Saccharomyces cerevisiae Provides a molecular basis for recruitment of the AAA peroxin Pex6p to peroxisomal membranes. Mol. Biol. Cell 14, 2226-2236. doi: 10.1091/mbc.E02-11-0752

Brennand, A., Rigden, D. J., and Michels, P. A. (2012) Trypanosomes contain two highly different isoforms of peroxin PEX13 involved in glycosome biogenesis. FEBS Lett. 586, 1765-1771. doi: 10.1016/j.febslet.2012.05.019

Brocard, C., and Hartig, A. (2006). Peroxisome targeting signal 1 : is it really a simple tripeptide? Biochim.
Biophys. Acta 1763, 1565-1573. doi: 10.1016/j.bbamcr.2006.08.022

Carvalho, A. F., Pinto, M. P., Grou, C. P., Alencastre, I. S., Fransen, M., Sa-Miranda, C., et al. (2007). Ubiquitination of mammalian Pex5p, the peroxisomal import receptor. J. Biol. Chem. 282, 31267-31272. doi: 10.1074/jbc.M706325200

Chowdhary, G., Kataya, A. R., Lingner, T., and Reumann, S. (2012). Noncanonical peroxisome targeting signals: identification of novel PTS1 tripeptides and characterization of enhancer elements by computational permutation analysis. BMC Plant Biol. 12:142. doi 10.1186/1471-2229-12-142

Cui, S., Fukao, Y., Mano, S., Yamada, K., Hayashi, M., and Nishimura, M. (2013). Proteomic analysis reveals that the Rab GTPase RabElc is involved in the degradation of the peroxisomal protein receptor PEX7 (peroxin 7). J. Biol.Chem. 288, 6014-6023. doi: 10.1074/jbc.M112. 438143

Cyr, N., Madrid, K. P., Strasser, R., Aurousseau, M., Finn, R., Ausio, J., et al. (2008). Leishmania donovani peroxin 14 undergoes a marked conformational change following association with peroxin 5. J. Biol. Chem. 283, 31488-31499. doi: 10.1074/jbc.M803529200

Dammai, V., and Subramani, S. (2001). The human peroxisomal targeting signal receptor, pex5p, is translocated into the peroxisomal matrix and recycled to the cytosol. Cell 105, 187-196. doi: 10.1016/S00928674(01)00310-5

Debelyy, M. O., Platta, H. W., Saffian, D., Hensel, A., Thoms, S., Meyer, H. E., et al. (2011). Ubp15p, a ubiquitin hydrolase associated with the peroxisomal export machinery. J. Biol. Chem. 286, 28223-28234. doi: 10.1074/jbc.M111.238600

Dixit, E., Boulant, S., Zhang, Y., Lee, A. S., Odendall, C., Shum, B. et al. (2010). Peroxisomes are signaling platforms for antiviral innate immunity. Cell 141, 668-681. doi 10.1016/j.cell.2010.04.018

El Magraoui, F., Bäumer, B. E., Platta, H. W., Baumann, J. S., Girzalsky, W., and Erdmann, R. (2012). The RING-type ubiquitin ligases Pex2p, Pex10p and Pex12p form a heteromeric complex that displays enhanced activity in an ubiquitin conjugating enzyme-selective manner. FEBS J. 279, 2060-2070. doi: 10.1111/j.1742-4658.2012.08591.x 
Erdmann, R., and Schliebs, W. (2005). Peroxisomal matrix protein import: the transient pore model. Nat. Rev. Mol. Cell Biol. 6, 738-742. doi: $10.1038 / \mathrm{nrm} 1710$

Fagarasanu, A., Mast, F. D., Knoblach, B., and Rachubinski, R. A. (2010). Molecular mechanism of organelle inheritance: lessons from peroxisomes in yeast. Nat. Rev. Mol. Cell Biol. 11, 644-654. doi: 10.1038/nrm2960

Faust, J. E., Verma, A., Peng, C., and Mcnew, J. A. (2012). An inventory of peroxisomal proteins and pathways in Drosophila melanogaster. Traffic 13, 1378-1392. doi: 10.1111/j.16000854.2012.01393.x

Fodor, K., Wolf, J., Erdmann, R., Schliebs, W., and Wilmanns, M. (2012). Molecular requirements for peroxisomal targeting of alanine-glyoxylate aminotransferase as an essential determinant in primary hyperoxaluria type 1 . PLoS Biol. 10:e1001309. doi: 10.1371/journal.pbio.1001309

Freitag, J., Ast, J., and Bölker, M. (2012). Cryptic peroxisomal targeting via alternative splicing and stop codon read-through in fungi. Nature 485, 522-525. doi: 10.1038/ nature11051

Freitas, M. O., Francisco, T., Rodrigues, T. A., Alencastre, I. S., Pinto, M. P., Grou, C. P., et al. (2011). PEX5 protein binds monomeric catalase blocking its tetramerization and releases it upon binding the N-terminal domain of PEX14. J. Biol. Chem. 286, 40509-40519. doi: 10.1074/jbc.M111.287201

Fujiki, Y., Nashiro, C., Miyata, N., Tamura, S., and Okumoto, K. (2012). New insights into dynamic and functional assembly of the AAA peroxins, Pexlp and Pex6p, and their membrane receptor Pex26p in shuttling of PTS1-receptor Pex5p during peroxisome biogenesis. Biochim. Biophys. Acta 1823, 145-149. doi: 10.1016/j.bbamcr. 2011.10.012

Gabaldón, T. (2010). Peroxisome diversity and evolution. Philos. Trans. R. Soc. Lond. B Biol. Sci. 365, 765-773. doi: 10.1098/rstb. 2009.0240

Giordano, C. R., and Terlecky, S. R. (2012). Peroxisomes, cell senescence, and rates of aging. Biochim. Biophys. Acta. 1822, 1358-1362. doi: 10.1016/j.bbadis.2012.03.013

Girzalsky, W., Platta, H. W., and Erdmann, R. (2009). Protein transport across the peroxisomal membrane. Biol. Chem. 390, 745-751. doi: 10.1515/BC. 2009.104
Gonzalez, N. H., Felsner, G., Schramm, F. D., Klingl, A., Maier, U. G., and Bolte, K. (2011). A single peroxisomal targeting signal mediates matrix protein import in diatoms. PLoS ONE 6:e25316. doi: 10.1371/journal.pone. 0025316

Goto, S., Mano, S., Nakamori, C., and Nishimura, M. (2011). Arabidopsis ABERRANT PEROXISOME MORPHOLOGY9 Is a peroxin that recruits the PEX1-PEX6 complex to peroxisomes. Plant Cell 23, 1573-1587. doi: $10.1105 /$ tpc. 110.080770

Gouveia, A. M., Guimaraes, C. P., Oliveira, M. E., Reguenga, C., Sa-Miranda, C., and Azevedo, J. E. (2002). Characterization of the peroxisomal cycling receptor, Pex $5 \mathrm{p}$, using a cell-free in vitro import system. J. Biol. Chem. 278, 226-232. doi: $10.1074 / \mathrm{jbc}$ M209498200

Gouveia, A. M., Guimaraes, C. P., Oliveira, M. E., Sa-Miranda, C., and Azevedo, J. E. (2003). Insertion of Pex5p into the peroxisomal membrane is cargo protein-dependent. J. Biol. Chem. 278, 4389-4392. doi: 10.1074/jbc.C200650200

Gouveia, A. M., Reguenga, C., Oliveira, M. E., Sa-Miranda, C., and Azevedo, J. E. (2000). Characterization of peroxisomal Pex $5 p$ from rat liver: Pex5p in the Pex5p-Pex14p membrane complex is a transmembrane protein. J. Biol. Chem. 275, 32444-32451. doi: 10.1074/jbc.M004366200

Grimm, I., Saffian, D., Platta, H. W., and Erdmann, R. (2012). The AAA-type ATPases Pexlp and Pex6p and their role in peroxisomal matrix protein import in Saccharomyces cerevisiae. Biochim. Biophys. Acta 1823, 150-158. doi: 10.1016/j.bbamcr. 2011.09.005

Grou, C. P., Carvalho, A. F., Pinto, M. P., Alencastre, I. S., Rodrigues, T. A., Freitas, M. O., et al. (2009a) The peroxisomal protein import machinery-a case report of transient ubiquitination with a new flavor. Cell Mol. Life Sci. 66, 254-262. doi: 10.1007/s00018-008-8415-5

Grou, C. P., Carvalho, A. F., Pinto, M. P., Huybrechts, S. J., Sa-Miranda, C., Fransen, M., et al. (2009b). Properties of the ubiquitin-Pex5p thiol ester conjugate. J. Biol. Chem. 284, 10504-10513. doi: 10.1074/jbc.M808978200

Grou, C. P., Carvalho, A. F., Pinto, M. P., Wiese, S., Piechura, H., Meyer, H. E., et al. (2008). Members of the E2D (UbcH5) family mediate the ubiquitination of the conserved cysteine of Pex5p, the peroxisomal import receptor. J. Biol. Chem. 283, 14190-14197. doi: 10.1074/jbc.M800402200

Grou, C. P., Francisco, T., Rodrigues, T. A., Freitas, M. O., Pinto, M. P., Carvalho, A. F., et al. (2012) Identification of ubiquitinspecific protease 9X (USP9X) as a deubiquitinase acting on the ubiquitin-peroxin 5 (PEX5) thioester conjugate. J. Biol. Chem. 287, 12815-12827. doi 10.1074/jbc.M112.340158

Gründlinger, M., Yasmin, S., Lechner, B. E., Geley, S., Schrettl, M., Hynes, M., et al. (2013). Fungal siderophore biosynthesis is partially localized in peroxisomes. Mol. Microbiol. 88, 862-875. doi: $10.1111 / \mathrm{mmi} .12225$

Grunau, S., Schliebs, W., Linnepe, R., Neufeld, C., Cizmowski, C., Reinartz, B., et al. (2009). Peroxisomal targeting of PTS2 pre-import complexes in the yeast Saccharomyces cerevisiae. Traffic 10, 451-460. doi: 10.1111/j.1600-0854.2008.00876.x

Gualdrón-López, M., Brennand, A., Hannaert, V., Quiñones, W., Cáceres, A. J., Bringaud, F., et al. (2012). When, how and why glycolysis became compartmentalised in the Kinetoplastea. A new look at an ancient organelle. Int. J. Parasitol. 42, 1-20. doi: 10.1016/j.ijpara.2011.10.007

Gunkel, K., Van Dijk, R., Veenhuis, M., and Van Der Klei, I. J. (2004). Routing of Hansenula polymorpha alcohol oxidase: an alternative peroxisomal protein sorting machinery. Mol. Biol. Cell 15, 1347-1355. doi: 10.1091/mbc.E03-04-025

Hampton, R. Y., and Sommer, T. (2012). Finding the will and the way of ERAD substrate retrotranslocation. Curr. Opin. Cell Biol. 24, 460-466. doi: 10.1016/j.ceb.2012.05.010

Hazra, P. P., Suriapranata, I., Snyder, W. B., and Subramani, S. (2002). Peroxisome remnants in pex3Delta cells and the requirement of Pex $3 p$ for interactions between the peroxisomal docking and translocation subcomplexes. Traffic 3, 560-574. doi: 10.1034/j.1600-0854.2002.30806.x

Hensel, A., Beck, S., El Magraoui, F., Platta, H. W., Girzalsky, W. and Erdmann, R. (2011). Cysteinedependent ubiquitination of Pex18p is linked to cargo translocation across the peroxisomal membrane. J. Biol. Chem. 286, 43495-43505. doi: 10.1074/jbc.M111.286104

Hu, J., Baker, A., Bartel, B., Linka, N., Mullen, R. T., Reumann, S. et al. (2012). Plant peroxisomes: biogenesis and function. Plant Cell 24, 2279-2303. doi: 10.1105/tpc.112.096586

Idnurm, A., Giles, S. S., Perfect, J. R., and Heitman, J. (2007). Peroxisome function regulates growth on glucose in the basidiomycete fungus Cryptococcus neoformans. Eukaryot. Cell 6, 60-72. doi: 10.1128/EC.00214-06

Islinger, M., Grille, S., Fahimi, H. D., and Schrader, M. (2012). The peroxisome: an update on mysteries. Histochem. Cell Biol. 137, 547-574. doi: 10.1007/s00418-012-0941-4

Islinger, M., Li, K. W., Seitz, J., Völkl, A., and Lüers, G. H. (2009). Hitchhiking of $\mathrm{Cu} / \mathrm{Zn}$ superoxide dismutase to peroxisomesevidence for a natural piggyback import mechanism in mammals. Traffic 10, 1711-1721. doi: 10.1111/j.1600-0854.2009.00966.x

Joo, H. J., Kim, K. Y., Yim, Y. H., Jin, Y. X., Kim, H., Kim, M. Y., et al. (2010). Contribution of the peroxisomal acox gene to the dynamic balance of daumone production in Caenorhabditis elegans. J. Biol. Chem. 285, 29319-29325. doi: 10.1074/jbc.M110.122663

Jung, S., Marelli, M., Rachubinski, R. A., Goodlett, D. R., and Aitchison, J. D. (2010). Dynamic changes in the subcellular distribution of Gpdlp in response to cell stress. J. Biol. Chem. 285, 6739-6749. doi: 10.1074/jbc.M109.058552

Kaur, N., Zhao, Q., Xie, Q., and $\mathrm{Hu}$, J. (2013). Arabidopsis RING peroxins are E3 ubiquitin ligases that interact with two homologous ubiquitin receptor proteins(F). J. Integr. Plant. Biol. 55, 108-120. doi: 10.1111/jipb.12014

Kerssen, D., Hambruch, E., Klaas, W., Platta, H. W., De Kruijff, B., Erdmann, R., et al. (2006). Membrane association of the cycling peroxisome import receptor Pex5p. J. Biol. Chem. 281, 27003-27015. doi 10.1074/jbc.M509257200

Kiel, J. A., Emmrich, K., Meyer, H. E., and Kunau, W. H. (2005). Ubiquitination of the peroxisomal targeting signal type 1 receptor, Pex $5 p$, suggests the presence of a quality control mechanism during peroxisomal matrix protein import. J. Biol. Chem. 280, 1921-1930. doi 10.1074/jbc.M403632200

Kiel, J. A., Veenhuis, M., and Van Der Klei, I. J. (2006). PEX genes in fungal genomes: common, rare or redundant. Traffic 7, 1291-1303. doi: $\quad 10.1111 /$ j.1600-0854.2006 00479.x 
Klein, A. T., Van Den Berg, M., Bottger, G., Tabak, H. F., and Distel, B. (2002). Saccharomyces cerevisiae acyl-CoA oxidase follows a novel, non-PTS1, import pathway into peroxisomes that is dependent on Pex5p. J. Biol. Chem. 277, 25011-25019. doi: 10.1074/jbc.M203254200

Kou, J., Kovacs, G. G., Höftberger, R., Kulik, W., Brodde, A., ForssPetter, S., et al. (2011). Peroxisomal alterations in Alzheimer's disease. Acta Neuropathol. 122, 271-283. doi: 10.1007/s00401-011-0836-9

Kragt, A., Voorn-Brouwer, T., Van Den Berg, M., and Distel, B. (2005). The Saccharomyces cerevisiae peroxisomal import receptor Pex5p is monoubiquitinated in wild type cells. J. Biol. Chem. 280, 7867-7874. doi: 10.1074/jbc.M413553200

Krause, C., Rosewich, H., Woehler, A., and Gärtner, J. (2013). Functional analysis of PEX13 mutation in a Zellweger syndrome spectrum patient reveals novel homooligomerization of PEX13 and its role in human peroxisome biogenesis. Hum. Mol. Genet. 22, 3844-3857. doi: 10.1093/hmg/ ddt 238

Kurochkin, I. V., Mizuno, Y., Konagaya, A., Sakaki, Y., Schönbach, C., and Okazaki, Y. (2007). Novel peroxisomal protease Tysnd1 processes PTS1- and PTS2-containing enzymes involved in beta-oxidation of fatty acids. EMBO J. 26, 835-845. doi: 10.1038/sj.emboj.7601525

Lasorsa, F. M., Pinton, P., Palmieri, L., Scarcia, P., Rottensteiner, H., Rizzuto, R., et al. (2008). Peroxisomes as novel players in cell calcium homeostasis. J. Biol. Chem. 283, 15300-15308. doi: 10.1074/jbc.M800648200

Lazarow, P. B. (2006). The import receptor Pex7p and the PTS2 targeting sequence. Biochim. Biophys. Acta 1763, 1599-1604. doi: 10.1016/j.bbamcr.2006.08.011

Leon, S., Goodman, J. M., and Subramani, S. (2006a). Uniqueness of the mechanism of protein import into the peroxisome matrix: transport of folded, co-factorbound and oligomeric proteins by shuttling receptors. Biochim. Biophys. Acta 1763, 1552-1564. doi: 10.1016/j.bbamcr.2006.08.037

Leon, S., Zhang, L., Mcdonald, W. H., Yates, J. 3rd., Cregg, J. M., and Subramani, S. (2006b). Dynamics of the peroxisomal import cycle of PpPex20p: ubiquitin-dependent localization and regulation. J. Cell Biol. 172, 67-78. doi: 10.1083/jcb.200508096
Lingner, T., Kataya, A. R., Antonicelli, G. E., Benichou, A., Nilssen, K., Chen, X. Y., et al. (2011). Identification of novel plant peroxisomal targeting signals by a combination of machine learning methods and in vivo subcellular targeting analyses. Plant Cell 23, 1556-1572. doi: 10.1105/tpc.111.084095

Liu, X., Ma, C., and Subramani, S. (2012). Recent advances in peroxisomal matrix protein import. Curr. Opin. Cell Biol. 24, 484-489. doi: 10.1016/j.ceb.2012.05.003

Liu, X., and Subramani, S. (2013). Unique requirements for monoand polyubiquitination of the peroxisomal targeting signal coreceptor, Pex20. J. Biol. Chem. 288, 7230-7240. doi: 10.1074/jbc.M112. 424911

Lizard, G., Rouaud, O., Demarquoy, J., Cherkaoui-Malki, M., and Iuliano, L. (2012). Potential roles of peroxisomes in Alzheimer's disease and in dementia of the Alzheimer's type. J. Alzheimers Dis. 29, 241-254. doi: 10.3233/JAD-2011-111163

Ma, C., Hagstrom, D., Polley, S. G., and Subramani, S. (2013) Redox regulated cargo binding and release by the peroxisomal targeting signal receptor, Pex5. J. Biol. Chem. doi: 10.1074/jbc.M113.492694. [Epub ahead of print].

Ma, C., Schumann, U., Rayapuram, N., and Subramani, S. (2009). The peroxisomal matrix import of Pex $8 p$ requires only PTS receptors and Pex14p. Mol. Biol. Cell 20, 3680-3689. doi: 10.1091/mbc.E09-01-0037

Managadze, D., Würtz, C., Wiese, S., Schneider, M., Girzalsky, W., Meyer, H. E., et al. (2010). Identification of PEX33, a novel component of the peroxisomal docking complex in the filamentous fungus Neurospora crassa. Eur. J. Cell Biol. 89, 955-964. doi: 10.1016/j.ejcb. 2010.07.003

Manivannan, S., Scheckhuber, C. Q., Veenhuis, M., and Van Der Klei, I. J. (2012). The impact of peroxisomes on cellular aging and death. Front. Oncol. 2:50. doi: 10.3389/fonc. 2012.00050

Matsumoto, N., Tamura, S., and Fujiki, Y. (2003). The pathogenic peroxin Pex26p recruits the Pexlp-Pex6p AAA ATPase complexes to peroxisomes. Nat. Cell. Biol. 5, 454-460. doi: $10.1038 /$ ncb982

Meijer, W. H., Gidijala, L., Fekken, S., Kiel, J. A., Van Den Berg, M. A., Lascaris, R., et al. (2010). Peroxisomes are required for efficient penicillin biosynthesis in
Penicillium chrysogenum. Appl. Environ. Micobiol. 76, 5702-5709. doi: 10.1128/AEM.02327-09

Meinecke, M., Cizmowski, C., Schliebs, W., Kruger, V., Beck, S., Wagner, R., et al. (2010). The peroxisomal importomer constitutes a large and highly dynamic pore. Nat. Cell Biol. 12, 273-277. doi: 10.1038/ncb2027

Miyata, N., and Fujiki, Y. (2005). Shuttling mechanism of peroxisome targeting signal type 1 receptor Pex5: ATP-independent import and ATP-dependent export. Mol. Cell Biol. 25, 10822-10832. doi: $\quad$ 10.1128/MCB.25.24.1082210832.2005

Miyata, N., Hosoi, K., Mukai, S., and Fujiki, Y. (2009). In vitro import of peroxisome-targeting signal type 2 (PTS2) receptor Pex7p into peroxisomes. Biochim. Biophys. Acta 1793, 860-870. doi: 10.1016/j.bbamcr.2009.02.007

Miyata, N., Okumoto, K., Mukai, S., Noguchi, M., and Fujiki, Y. (2012). AWP1/ZFAND6 Functions in Pex5 Export by Interacting with Cys-monoubiquitinated Pex5 and Pex6 AAA ATPase. Traffic 13, 168-183. doi: 10.1111/j.1600-0854.2011.01298.x

Mizuno, Y., Ninomiya, Y., Nakachi, Y., Iseki, M., Iwasa, H., Akita, M., et al. (2013). Tysnd1 deficiency in mice interferes with the peroxisomal localization of PTS2 enzymes, causing lipid metabolic abnormalities and male infertility. PLoS Genet. 9:e1003286. doi: 10.1371/journal.pgen.1003286

Motley, A. M., Hettema, E. H., Ketting, R., Plasterk, R., and Tabak, H. F. (2000). Caenorhabditis elegans has a single pathway to target matrix proteins to peroxisomes. EMBO Rep. 1, 40-46. doi: 10.1093/emboreports/kvd010

Nagotu, S., Kalel, V. C., Erdmann, R., and Platta, H. W. (2012). Molecular basis of peroxisomal biogenesis disorders caused by defects in peroxisomal matrix protein import. Biochim. Biophys. Acta 1822, 1326-1336. doi: 10.1016/j.bbadis.2012.05.010

Nair, D. M., Purdue, P. E., and Lazarow, P. B. (2004). Pex7p translocates in and out of peroxisomes in Saccharomyces cerevisiae. J. Cell Biol. 167, 599-604. doi: 10.1083/jcb.200407119

Nashiro, C., Kashiwagi, A., Matsuzaki, T., Tamura, S., and Fujiki, Y. (2011). Recruiting mechanism of the AAA peroxins, Pexlp and Pex6p, to Pex26 on peroxisome membrane. Traffic 12, 774-788. doi: 10.1111/j.1600-0854.2011.01182.x
Natsuyama, R., Okumoto, K., and Fujiki, Y. (2013). Pex5p stabilizes Pex14p: a study using a newly isolated pex5 $\mathrm{CHO}$ cell mutant, ZPEG101. Biochem. J. 449, 195-207. doi: 10.1042/BJ20120911

Neufeld, C., Filipp, F. V., Simon, B., Neuhaus, A., Schüller, N., David, C., et al. (2009). Structural basis for competitive interactions of Pex14 with the import receptors Pex 5 and Pex19. EMBO J. 28, 745-754. doi: 10.1038/emboj.2009.7

Niederhoff, K., Meindl-Beinker, N. M., Kerssen, D., Perband, U., Schäfer, A., Schliebs, W., et al. (2005). Yeast Pex14p possesses two functionally distinct Pex5p and one Pex7p binding sites. J. Biol. Chem. 280, 35571-35578. doi: 10.1074/jbc.M502460200

Oeljeklaus, S., Reinartz, B. S., Wolf, J., Wiese, S., Tonillo, J., Podwojski, K., et al. (2012). Identification of core components and transient interactors of the peroxisomal importomer by dual-track stable isotope labeling with amino acids in cell culture analysis. J. Proteome Res. 11, 2567-2580. doi: 10.1021/pr3000333

Okumoto, K., Kametani, Y., and Fujiki, Y. (2011a). Two proteases, Tysnd1 and PsLon, cooperatively regulate fatty-acid \{beta\}-oxidation in the peroxisomal matrix. J. Biol. Chem. 286, 44367-44379. doi: 10.1074/jbc.M111.285197

Okumoto, K., Misono, S., Miyata, N., Matsumoto, Y., Mukai, S., and Fujiki, Y. (2011b). Cysteine ubiquitination of PTS1 receptor Pex5p regulates Pex5p recycling. Traffic 12, 1067-1083. doi: 10.1111/j.16000854.2011.01217.x

Opaliński, L., Kiel, J. A., Homan, T. G., Veenhuis, M., and Van Der Klei, I. J. (2010). Penicillium chrysogenum Pex14/17p-a novel component of the peroxisomal membrane that is important for penicillin production. FEBS J. 277, 3203-3218. doi: 10.1111/j.1742-4658.2010.07726.x

Otera, H., and Fujiki, Y. (2011). Pex5p imports folded tetrameric catalase by interaction with Pex13p. Traffic 13, 1364-1377. doi: 10.1111/j.16000854.2012.01391.x

Palmer, T., and Berks, B. C. (2012). The twin-arginine translocation (Tat) protein export pathway. Nat. Rev. Microbiol. 10, 483-496. doi: 10.1038/nrmicro2814

Peraza-Reyes, L., Arnaise, S., Zickler, D., Coppin, E., Debuchy, R., and Berteaux-Lecellier, V. (2011). The importomer peroxins are differentially required for peroxisome assembly and meiotic development in Podospora anserina: 
insights into a new peroxisome import pathway. Mol. Microbiol. 82, 365-377. doi: 10.1111/j.1365-2958. 2011.07816.x

Petriv, O. I., Tang, L., Titorenko, V. I., and Rachubinski, R. A. (2004). A new definition for the consensus sequence of the peroxisome targeting signal type 2 . J. Mol. Biol. 341, 119-134. doi: 10.1016/j.jmb.2004.05.064

Pieuchot, L., and Jedd, G. (2012). Peroxisome assembly and functional diversity in eukaryotic microorganisms. Annu. Rev. Microbiol. 66, 237-263. doi: $\quad 10.1146 /$ annurev-micro092611-150126

Pires, J. R., Hong, X., Brockmann, C., Volkmer-Engert, R., SchneiderMergener, J., Oschkinat, H., et al. (2003). The ScPex13p SH3 domain exposes two distinct binding sites for Pex5p and Pex14p. J. Mol. Biol. 326, 1427-1435. doi: $\quad 10.1016 /$ S0022-2836(03) 00039-1

Platta, H. W., Debelyy, M. O., El Magraoui, F., and Erdmann, R. (2008). The AAA peroxins Pexlp and Pex6p function as dislocases for the ubiquitinated peroxisomal import receptor Pex5p. Biochem. Soc. Trans. 36, 99-104. doi: 10.1042/BST0360099

Platta, H. W., El Magraoui, F., Baumer, B. E., Schlee, D., Girzalsky, W., and Erdmann, R. (2009). Pex2 and Pex12 function as protein-ubiquitin ligases in peroxisomal protein import. Mol. Cell. Biol. 29, 5505-5516. doi: 10.1128/MCB.00388-09

Platta, H. W., El Magraoui, F., Schlee, D., Grunau, S., Girzalsky, W., and Erdmann, R. (2007). Ubiquitination of the peroxisomal import receptor Pex5p is required for its recycling. J. Cell. Biol. 177, 197-204. doi: 10.1083/jcb.200611012

Platta, H. W., and Erdmann, R. (2007). Peroxisomal dynamics. Trends Cell Biol. 17, 474-484. doi: 10.1016/j.tcb.2007.06.009

Platta, H. W., Girzalsky, W., and Erdmann, R. (2004). Ubiquitination of the peroxisomal import receptor Pex5p. Biochem. J. 384, 37-45. doi: 10.1042/BJ20040572

Platta, H. W., Grunau, S., Rosenkranz, K., Girzalsky, W., and Erdmann, R. (2005). Functional role of the AAA peroxins in dislocation of the cycling PTS1 receptor back to the cytosol. Nat. Cell Biol. 7, 817-822. doi: $10.1038 /$ ncb1281

Platta, H. W., Hagen, S., and Erdmann, R. (2013). The exportomer: the peroxisomal receptor export machinery. Cell Mol. Life Sci. 70, 1393-1411. doi: 10.1007/s00018-012-1136-9

Poll-the, B. T., and Gärtner, J. (2012). Clinical diagnosis, biochemical findings and MRI spectrum of peroxisomal disorders. Biochim. Biophys. Acta 1822, 1421-1429. doi: 10.1016/j.bbadis. 2012.03.011

Purdue, P. E., and Lazarow, P. B. (2001). Pex $18 p$ is constitutively degraded during peroxisome biogenesis. J. Biol. Chem. 276, 47684-47689. doi: 10.1074/jbc.M106823200

Ratzel, S. E., Lingard, M. J., Woodward, A. W., and Bartel, B. (2011). Reducing PEX13 expression ameliorates physiological defects of late-acting peroxin mutants. Traffic 12, 121-134. doi: 10.1111/j.1600-0854. 2010.01136.x

Schell-Steven, A., Stein, K., Amoros, M., Landgraf, C., Volkmer-Engert, R., Rottensteiner, H., et al. (2005). Identification of a novel, intraperoxisomal pex14-binding site in pex13: association of pex13 with the docking complex is essential for peroxisomal matrix protein import. Mol. Cell. Biol. 25, 3007-3018. doi: $\quad$ 10.1128/MCB.25.8.30073018.2005

Schliebs, W., Girzalsky, W., and Erdmann, R. (2010). Peroxisomal protein import and ERAD: variations on a common theme. Nat. Rev. Mol. Cell Biol. 11, 885-890. doi: 10.1038/nrm3008

Schliebs, W., and Kunau, W. H. (2006). PTS2 co-receptors: diverse proteins with common features. Biochim. Biophys. Acta 1763, 1606-1612. doi: 10.1016/j.bbamcr. 2006.08.051

Schlüter, A., Fourcade, S., Ripp, R., Mandel, J. L., Poch, O., and Pujol, A. (2006). The evolutionary origin of peroxisomes: an ER-peroxisome connection. Mol. Biol. Evol. 23, 838-845. doi: 10.1093/molbev/msj103

Schlüter, A., Real-Chicharro, A., Gabaldón, T., Sánchez-Jiménez, F., and Pujol, A. (2010). PeroxisomeDB 2.0: an integrative view of the global peroxisomal metabolome. Nucleic Acids Res. 38, D800-D805. doi: 10.1093/nar/ gkp935

Schnell, D. J., and Hebert, D. N. (2003). Protein translocons: multifunctional mediators of protein translocation across membranes. Cell 112, 491-505. doi: 10.1016/S0092-8674(03)00110-7

Schuhmann, H., Huesgen, P. F., Gietl, C., and Adamska, I. (2008). The
DEG15 serine protease cleaves peroxisomal targeting signal 2containing proteins in Arabidopsis. Plant Physiol. 148, 1847-1856. doi: 10.1104/pp.108.125377

Shiozawa, K., Konarev, P. V., Neufeld, C., Wilmanns, M., and Svergun, D. I. (2009). Solution structure of human Pex5.Pex14.PTS1 protein complexes obtained by small angle X-ray scattering. J. Biol. Chem. 284, 25334-25342. doi: 10.1074/jbc.M109.002311

Spiegel, C. N., Batista-Pereira, L. G., Bretas, J. A., Eiras, A. E. Hooper, A. M., Peixoto, A. A., et al. (2011). Pheromone gland development and pheromone production in lutzomyia longipalpis (Diptera: Psychodidae: Phlebotominae). J. Med. Entomol. 48, 489-495. doi: 10.1603/ ME10133

Stanley, W. A., Filipp, F. V., Kursula, P., Schüller, N., Erdmann, R., Schliebs, W., et al. (2006). Recognition of a functional peroxisome type 1 target by the dynamic import receptor pex5p. Mol. Cell 24, 653-663. doi: 10.1016/j.molcel. 2006.10.024

Su, J. R., Takeda, K., Tamura, S. Fujiki, Y., and Miki, K. (2009). Crystal structure of the conserved $\mathrm{N}$-terminal domain of the peroxisomal matrix protein import receptor, Pex14p. Proc. Natl. Acad. Sci. U.S.A. 106, 417-421. doi: 10.1073/pnas.0808681106

Su, J. R., Takeda, K., Tamura, S. Fujiki, Y., and Miki, K. (2010). Monomer-dimer transition of the conserved N-terminal domain of the mammalian peroxisomal matrix protein import receptor, Pex14p.. Biochem. Biophys. Res. Commun. 394, 217-221. doi: 10.1016/j.bbrc.2010.02.160

Theodoulou, F. L., Bernhardt, K., Linka, N., and Baker, A. (2013). Peroxisome membrane proteins: multiple trafficking routes and multiple functions? Biochem. J. 451, 345-352. doi: 10.1042/ BJ20130078

Titorenko, V. I., Nicaud, J. M., Wang, H., Chan, H., and Rachubinski, R. A. (2002). Acyl-CoA oxidase is imported as a heteropentameric, cofactor-containing complex into peroxisomes of Yarrowia lipolytica. J. Cell Biol. 156, 481-494. doi: 10.1083/jcb.200111075

Van Der Klei, I. J., and Veenhuis, M. (2006). PTS1-independent sorting of peroxisomal matrix proteins by Pex5p. Biochim. Biophys. Acta 1763 , 1794-1800. doi: 10.1016/j.bbamcr. 2006.08.013
Verplaetse, E., Gualdrón-López, M., Chevalier, N., and Michels, P. A. (2012). Studies on the organization of the docking complex involved in matrix protein import into glycosomes of Trypanosoma brucei. Biochem. Biophys. Res. Commun. 424, 781-785. doi: 10.1016/j.bbrc.2012.07.035

Visser, W. F., Van Roermund, C. W., Ijlst, L., Waterham, H. R., and Wanders, R. J. (2007). Metabolite transport across the peroxisomal membrane. Biochem. J. 401, 365-375. doi: 10.1042/ BJ20061352

Wanders, R. J., and Waterham, $\mathrm{H}$. R. (2006). Biochemistry of mammalian peroxisomes revisited Annu. Rev. Biochem. 75, 295-332. doi: 10.1146/annurev.biochem.74. 082803.133329

Wang, D., Visser, N. V., Veenhuis, M., and Van Der Klei, I. J. (2003). Physical interactions of the peroxisomal targeting signal 1-receptor, Pex5p, studied by fluorescence correlation spectroscopy. J. Biol. Chem. 278, 43340-43345. doi: 10.1074/jbc.M307789200

Waterham, H. R., and Ebberink, M. S. (2012). Genetics and molecular basis of human peroxisome biogenesis disorders. Biochim. Biophys. Acta 1822, 1430-1441. doi: 10.1016/j.bbadis. 2012.04.006

Widhalm, J. R., Ducluzeau, A. L., Buller, N. E., Elowsky, C. G., Olsen, L. J., and Basset, G. J. (2012). Phylloquinone (Vitamin $\mathrm{K}(1)$ ) biosynthesis in plants: two peroxisomal thioesterases of lactobacillales origin Hydrolyze 1,4-Dihydroxy2-Naphthoyl-Coa. Plant J. 71, 205-215. doi: 10.1111/j.1365313X.2012.04972.x

Williams, C., and Distel, B. (2006). Pex13p: docking or cargo handling protein? Biochim. Biophys. Acta 1763, 1585-1591. doi: 10.1016/j.bbamcr.2006.09.007

Williams, C., Van Den Berg, M., Geers, E., and Distel, B. (2008). Pex10p functions as an E3 ligase for the Ubc4p-dependent ubiquitination of Pex5p. Biochem. Biophys. Res. Commun. 374 620-624. doi: 10.1016/j.bbrc 2008.07.054

Williams, C., Van Den Berg, M., Panjikar, S., Stanley, W. A., Distel, B., and Wilmanns, M. (2012). Insights into ubiquitinconjugating enzyme/ co-activator interactions from the structure of the Pex4p:Pex $22 \mathrm{p}$ complex. EMBO J. 31, 391-402. doi: 10.1038/emboj.2011.411 
Williams, C., Van Den Berg, M., Sprenger, R. R., and Distel, B. (2007). A conserved cysteine is essential for Pex4p-dependent ubiquitination of the peroxisomal import receptor Pex5p. J. Biol. Chem. 282, 22534-22543. doi: 10.1074/jbc.M702038200

Yang, X., Purdue, P. E., and Lazarow, P. B. (2001). Ecilp uses a PTS1 to enter peroxisomes: either its own or that of a partner, Dcilp. Eur. J. Cell. Biol. 80, 126-138. doi: 10.1078/01719335-00144

Zipor, G., Brocard, C., and Gerst, J. E. (2011). Isolation of mRNAs encoding peroxisomal proteins from yeast using a combined cell fractionation and affinity purification procedure. Methods Mol. Biol. 714, 323-333. doi: $\quad 10.1007 / 978-1-61779$ 005-8_20

Zipor, G., Haim-Vilmovsky, L., GelinLicht, R., Gadir, N., Brocard, C., and Gerst, J. E. (2009). Localization of mRNAs coding for peroxisomal proteins in the yeast, Saccharomyces cerevisiae. Proc. Natl. Acad. Sci. U.S.A. 106, 19848-19853. doi: 10.1073/pnas. 0910754106
Conflict of Interest Statement: The authors declare that the research was conducted in the absence of any commercial or financial relationships that could be construed as a potential conflict of interest.

Received: 03 July 2013; paper pending published: 12 August 2013; accepted: 03 September 2013; published online: 24 September 2013.

Citation: Hasan S, Platta HW and Erdmann $R$ (2013) Import of proteins into the peroxisomal matrix. Front. Physiol. 4:261. doi: 10.3389/fphys. 2013.00261
This article was submitted to Integrative Physiology, a section of the journal Frontiers in Physiology.

Copyright (c) 2013 Hasan, Platta and Erdmann. This is an open-access article distributed under the terms of the Creative Commons Attribution License (CC BY). The use, distribution or reproduction in other forums is permitted, provided the original author(s) or licensor are credited and that the original publication in this journal is cited, in accordance with accepted academic practice. No use, distribution or reproduction is permitted which does not comply with these terms. 